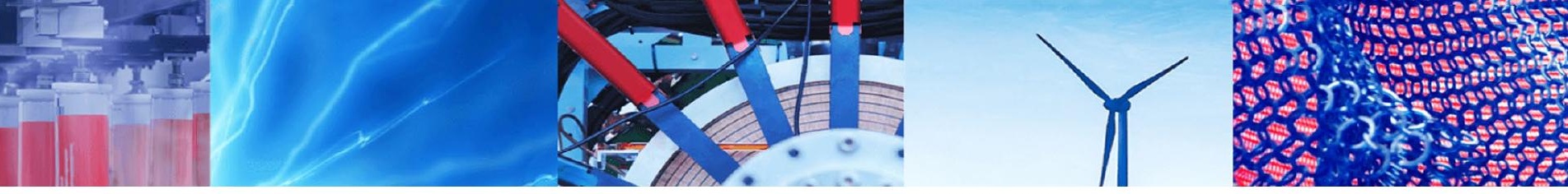

Review Paper

\title{
Exposure effect to cement dust pollution: a mini review
}

\author{
Emmanuel Adeyanju' ${ }^{1} \cdot$ Chukwueloka Austin Okeke $^{1}$
}

Received: 9 June 2019 / Accepted: 29 October 2019 / Published online: 8 November 2019

(c) Springer Nature Switzerland AG 2019

\begin{abstract}
The aim of this paper is to illuminate the impacts of cement production emissions on the environment. Various research work has shown that countries in sub-Saharan Africa, suffer the most from environmental pollution especially air pollution. One of such contributing factors is the behavioural pattern of workers and traders living close to production plants. Significantly also, data are not available in this region. The need for cement as well as the presence of local raw materials, coupled with the need for local content has resulted in an increase in the number of cement plants. Areas within and around the cement plant are exposed to various air pollutants. These pollutants affect the life and wellbeing of workers, children and people in close communities as well as the flora and fauna. Diseases such as chronic obstructive pulmonary, silicosis, preterm delivery, psychasthenia, endocrine disruption, cancer and infertility are associated with these pollutants. This paper describes the impacts of these pollutants on human's health and plant's growth as well as where studies should focus on in the future. Various high impact papers were selected and cogent findings as it affects different classes of people were discussed in this paper. It is recommended that more data collection, pollutant characterization, risk assessment and dispersion analysis should be carried out in developing countries. More research should be undertaken to determine the impact of alternative fuel and the effectiveness of dust control technologies used in various cement plants.
\end{abstract}

Keywords Cement plant · Air pollution · Environmental impact $\cdot$ Cement plant exposure

\section{Introduction global pollution and cement contribution}

Data released by the World Health Organization (WHO) in 2018, showed that 9 in 10 people inhaled air that contains high levels of pollutants above the safe limit defined by the WHO. It has been established that globally, about 7 million people die annually from polluted air related issues. The impacts are critical in Asia and Africa, where $90 \%$ of the air pollution related deaths have been recorded. Pollution index obtained from Numbeo, showed that Asia has a high pollution index while only a few countries in Africa have enough data for these analyses. Countries in both regions where data are available showed pollution index from average to maximum. Regions with above average pollution index are Africa, South America and Asia. This is due to an increase in industrialisation and urbanisation, fuel sources and bush burning, little or reduced regulation and enforcement [1]. The effects of this high pollution index across different regions were documented by WHO. Ischaemic heart disease is the highest recorded effect of pollution on human health as at the year 2018.

Globally, different pollutants are responsible for these diseases. This problem is not only in urban or industrialised area, as observed in Africa. In Africa, household pollution from cooking and burning of fossil fuel even in rural areas contributes to this issue. Different sectors and processes contribute to the emission of different air pollutants, and their contribution varies from region to region and therefore, country to country. Different pollutants

Emmanuel Adeyanju, Emmanuel.adeyanju@stu.cu.edu.ng | ${ }^{1}$ Department of Civil Engineering, Covenant University, Ota, Ogun State, Nigeria. 
are responsible for air pollution but the most common include, particulate matter (PM), oxides of nitrogen $\left(\mathrm{NO}_{x}\right)$, carbon monoxide (CO), sulfur dioxide $\left(\mathrm{SO}_{2}\right)$ and volatile organic compounds. The European Environment Agency reported that commercial, institutional and household activities contribute the highest for $\mathrm{PM}_{10}$ emission, followed by industrial emission. $\mathrm{PM}_{2.5}$ is released majorly from commercial, institutional and household, followed by road transport and industrial processes in the year 2013 as showed in Fig. 1.

One major source of pollution is industrial processes and consequently, one of such industrial processes includes the cement production. A single cement plant emits a large amount of pollutants into the atmosphere. Furthermore, an increase in production output or change in fuel type and usage as well as dust control technology affects the volume and concentration of contaminant released. Several studies and reports have recognized cement production as the biggest source of PM emission accounting for $20-30 \%$ which is $40 \%$ of the total industrial emission $[2,3]$.

Global increase in urbanisation has led to an upsurge in cement demand [4]. The need for local content, availability of raw materials and local demand has resulted in the establishment of more cement plants [5-7]. Globally, it was estimated that 2.18 billion tonnes of cement was produced in 2012 [8] while 4.3 billion tonnes of cement were produced in 2014 [4]. Several works and reports have credited China as the leading manufacturer of cement, accounting for $59.31 \%$ of the total cement produced worldwide [9, 10]. Corporate records from Nigeria have indicated that cement production increased from 28 million tonnes by 2013 , to 30.75 million tonnes in recent years [11].
The most exploited topic relating to cement production is its greenhouse gas (GHG) emission, which accounts for about $5-7 \%$ of global anthropogenic Carbon dioxide $\left(\mathrm{CO}_{2}\right)$ emission [12-14]. The contribution of this industry to $\mathrm{CO}_{2}$ production and proposed mitigation processes have been well detailed [15-18]. The amount of $\mathrm{CO}_{2}$ emitted by the cement industry is based on the demand for cement, kiln type, fuel used, efficiency of energy utilization as well as clinker to cement ratio.

Different articles have reported that $\mathrm{CO}_{2}$ emission from cement plants is not the only pollutant discharged into the atmosphere. In China, $4 \%$ of $\mathrm{SO}_{2}, 15-30 \%$ of PM and $10 \%$ of $\mathrm{NO}_{\mathrm{X}}$ released into the atmosphere annually were generated by the cement industry [16]. In addition, 0.89 , 1.69 and 3.58 million tonnes of $\mathrm{SO}_{2}, \mathrm{NO}_{x}$ and $\mathrm{PM}$ were discharged in the atmosphere in China alone in 2009 [10]. While in $2012,1.09,1.98$ and 0.67 million tonnes of $\mathrm{SO}_{2}$, $\mathrm{NO}_{\mathrm{X}}$ and $\mathrm{PM}$ respectively were emitted in China alone [8]. Different studies mentioned that for every 1380 Million tonnes of $\mathrm{CO}_{2}$ emitted, 410, 1.3 and 2.27 million tonnes of $\mathrm{PM}, \mathrm{SO}_{2}$ and $\mathrm{NO}_{\mathrm{X}}$ respectively were also released [19]. Through raw materials and fuel used during production, $1.17-1.53$ tons of mercury were emitted annually accounting for $10 \%$ the total mercury released globally $[20,21]$.

Presently, due to effective pollution management, emissions from cement plants are reduced. However, as cement production increase, even with reduced emission per plant or ton of cement produced, emissions would increase. A similar trend has been observed in various countries at different time frames. In China, through effective management, such as kiln type changes, and reduced cement production, reduced $\mathrm{SO}_{2}$ emission was recorded between the year 2004 and 2012. A historical trend of pollution
Fig. 1 PM pollution source in Europe

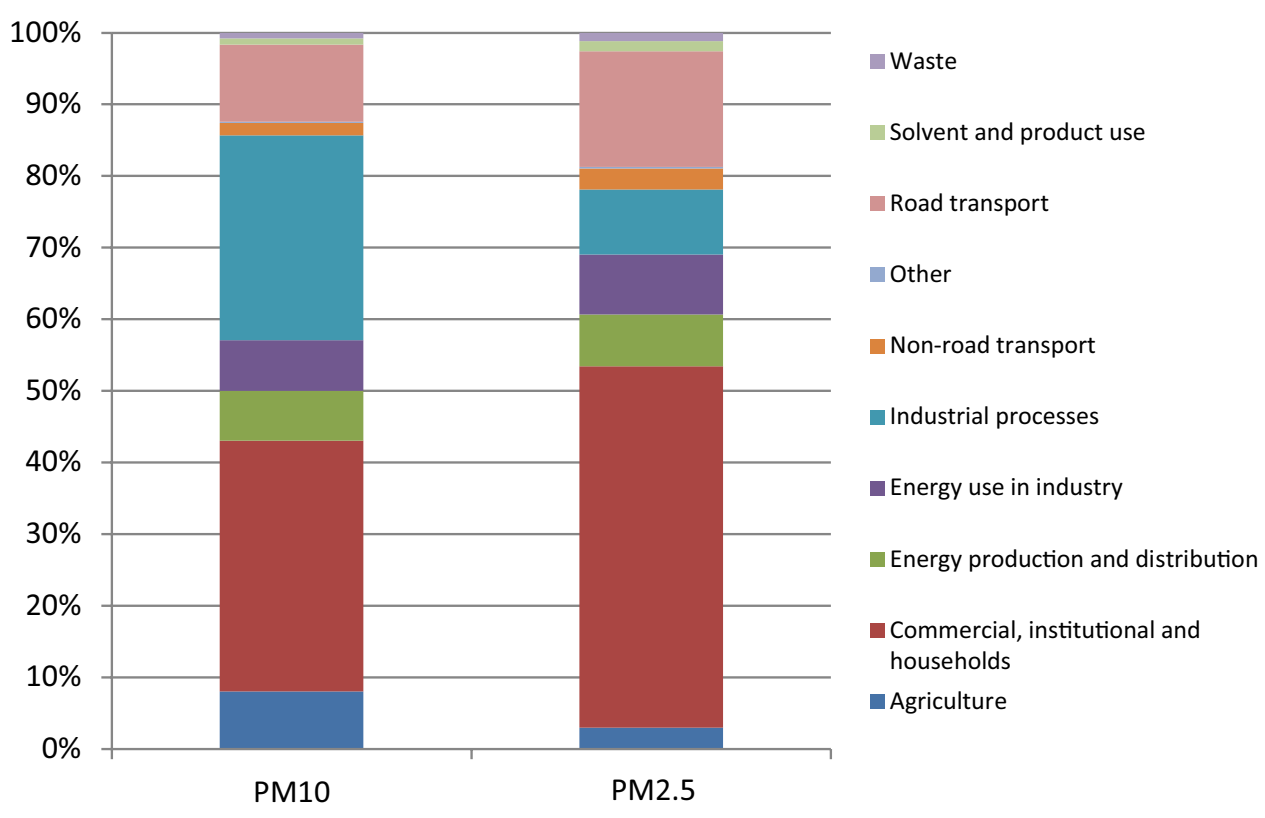


from cement plant in China from 1980 to 2012 shows that as China production increased exponentially, pollution increased, heavy metal emitted each year also amplified $[3,22]$ as illustrated in Fig. 2.

Dust emanates from different processes such as raw material handling, limestone crushing, kiln processing, clinker production and storage, finished cement grinding and power utilities $[14,23]$. Different models and modelling tools such as fugitive dust model (FDM) and AERMOD View emission dispersion modelling, have been used to examine pollution effects on neighbouring communities [23]. Modelling of air pollution or quality in developing countries such as Nigeria is limited [24]. Effective and unbiased monitoring of air quality around factories such as cement manufacturing plants is carried out by a handful of researchers in developing countries. Complaints of people or perceived health implications had necessitated such studies.

Different studies reported that residents around cement plants complained about air pollution [25-27]. In most cases, the thick layer of dust on parked cars or on roadways as well as befouled atmosphere created chaos and public outcry among residents near the plant. In most cases, these residents are unaware of the dangers associated with cement dust in their environment. These residents are continuously exposed to different pollutants of which they lack a basic understanding. Various researchers have worked on the environmental impact of cement plants built within residential communities or residential communities built so close to cement plants. Their findings have not been limited to the effects on human beings but also included the effects on plants and in a few cases, on the aquatic environment.

In these communities, children are the most vulnerable [28]. After which we have men and lastly females. There is a need to highlight various research works on the environmental impact of cement plant pollution. This paper will discuss the various types of pollutants, pollutant emission sources, effects on humans and plants.

\section{Methods}

Even though cement pollutants and impacts are being established, the level of effects on human health in developing countries is still unknown. Most observed effects of pollution from the cement industry on the environment are from developed countries. This review, generally examines the effects from regions where substantial data is available and studies have been well carried out in order to understand what studies need to be carried out in developing countries. With a focus on the health effects on humans, scientific articles from a systematic search with search phrases such as cement plant exposures, nonoccupational exposure to cement plant, pollutant dispersion from a cement plant was carried out. Different search database were explored, especially Web of Science, Sciencedirect and Google scholar. More research articles were identified by screening the citation and references of the papers obtained from the search results. Studies indicating risk of bias, inconsistency, imprecision and unclear methodology, indirectness, and uncollaborated conclusions were not included in this review. Data such as the general information: title, authors, country where the study was performed, study period and year of publication were collected. Also, the study design used such as ecological, case-control, cross-sectional, cohort, and time-series were collected. The number of subjects, their age distribution, spatial data, gender and findings was also gathered. The prevalence and, odds ratio $(\mathrm{OR})$, incidence rate, rate ratio (RR), standardized mortality ratio (SMR), standardized incidence ratio (SIR) and standardized density ratio (SDR) and
Fig. 2 Increase in heavy metal pollution as cement production increased [3]
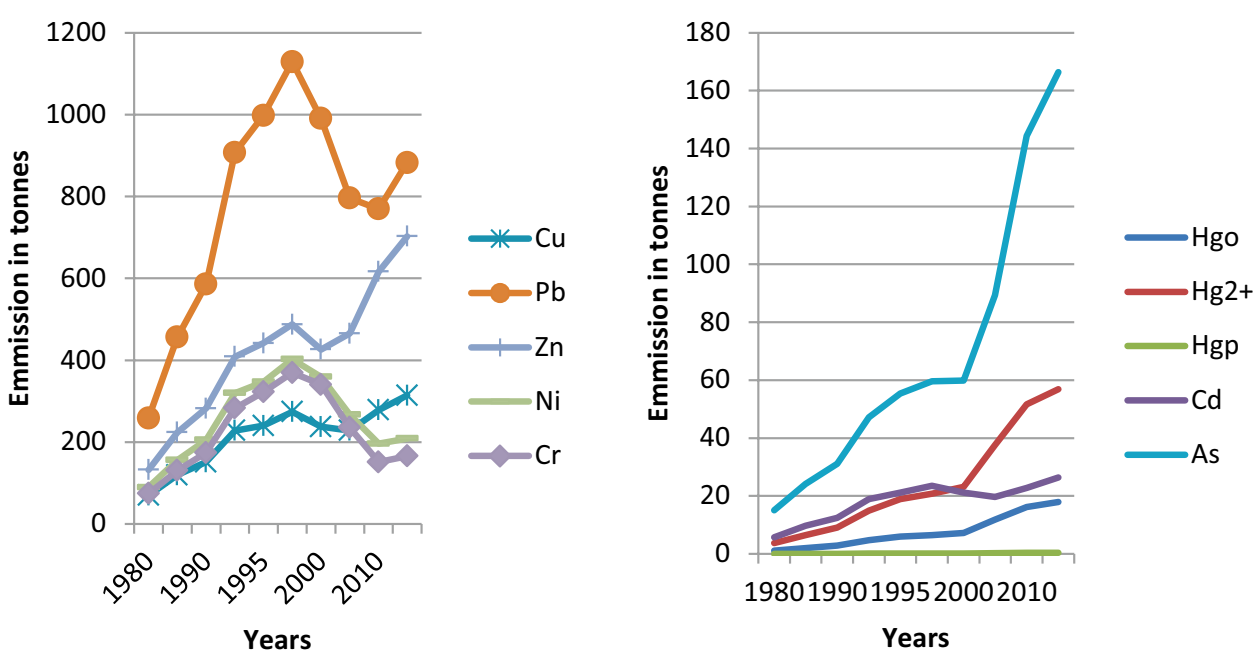

SN Applied Sciences A SPRINGER NATURE journal 
their $95 \%$ confidence intervals ( $95 \% \mathrm{Cls}$ ) were all recorded. Three ecological studies, three retrospective cohort studies, two case control studies and two cross sectional studies were considered. The keywords for this review article are Cement plant; Air pollution; Environmental impact; Cement plant exposure (Fig. 3).

\section{Pollutants, sources and classification}

Various research has shown that at different stages of cement production, there is release of dust $[23,29]$. The nature and amount of the raw materials as well as the topography, and weather conditions affect the concentration of the dust and dispersal patterns. Also, extensive work has shown that this dust does affect the health of people living around the cement plant. Air quality of areas within and around the plant are always affected [30-35].

Air pollutants from cement plants include $\mathrm{PM}, \mathrm{NO}_{\mathrm{x}}, \mathrm{CO}$, $\mathrm{SO}_{2}$ and volatile organic compounds, $\mathrm{O}_{3}, \mathrm{H}_{2} \mathrm{~S}$, (PCDD/Fs) and (PCBs) [36-42]. CO and Hydrocarbons is from incomplete combustion $[4,43]$ while $\mathrm{NO}_{x}$ is released during fuel combustion. $\mathrm{SO}_{2}$ is generated from raw materials used in cement production and from fuel sources $[4,14,44]$. The type of kiln used in a cement plant affects the amount of $\mathrm{SO}_{2}$ absorbed during production or emitted into the atmosphere [3]. $\mathrm{SO}_{2}$ is oxided after emission to $\mathrm{SO}_{3}$, where it is either absorbed by moist in the atmosphere, to form sulfate aerosols or acidified on surface water and soil [22].

The PM released from cement plants range from 0.05 to $10 \mu \mathrm{m}$ in diameter [45]. Their particles sizes ranges from micrometre to nanometres [2, 46-48]. Different researchers have reported that the particle size plays a role on the effects that different PM sizes have. $\mathrm{PM}_{2.5}$ is reported to be responsible for a lot of human health issues than other PM sizes $[49,50]$. PM sizes ranging from 10 to $2.5 \mu \mathrm{m}$ are accumulated in the upper part of the respiratory system while smaller PM goes deeper into the lung system and the blood stream.
Apart from the sizes, PM contain several components such as mineral matter, sea spray, organic matter and elemental carbon, secondary inorganic aerosols, trace elements and unknown elements or compounds. Several heavy metals such as Arsenic (As), Cadmium (Cd), Chromium ( $\mathrm{Cr})$, Nickel (Ni), Zinc ( $\mathrm{Zn}$ ) and Lead $(\mathrm{Pb})$ are among its trace element. Depending on exposure, concentration and individual sensitive, they can either be harmless or harmful [2]. Their forms could vary from salts to oxides to gaseous form to complex particles, with their toxicity depending on their chemical speciation.

A typical PM consists of the components listed above but the composition varies depending on various factors such as PM size, seasonal variation, the raw material combination, fuel used and traffic condition or other industrial activity surrounding the plant. These variation affects the PM size, concentration and composition [2]. The biggest problem about this characterization is the significant influence of traffic (vehicular emissions). To identify traffic influence, there is a need to take reading when only traffic PM can be recorded, and subtracted from PM reading when the cement plant influence is measured. But still, results will just be estimates as different conditions leading to PM emitted can vary on a day to day basis and even minutes basis. A comparison between when the cement is operational and not (work days and weekend) shows cement plants significantly influence trace element concentration. 'Clean' PM characterization has shown that certain trace elements can be traced to certain type of sources, such as Cobalt Co, Chromium ( $\mathrm{Cr}$ ), Manganese (Mn), and Antimony (Sb) to traffic, and Aluminum (Al), Calcuim (Ca), Nickel (Ni) and Vanadium (V) to cement plant. There variation or constant variation helps to estimate various effects [51]. Particle size distribution of the raw materials shows the primary source of this PM. Raw materials such as fly ash, coal + coke have large portion of particulates ranging from $\mathrm{PM}_{0.1}$ to $\mathrm{PM}_{10}$. The elemental compositions of the particles are dependent on the raw materials as well as the alternative fuel used.
Fig. 3 Flow diagram of the study selection process

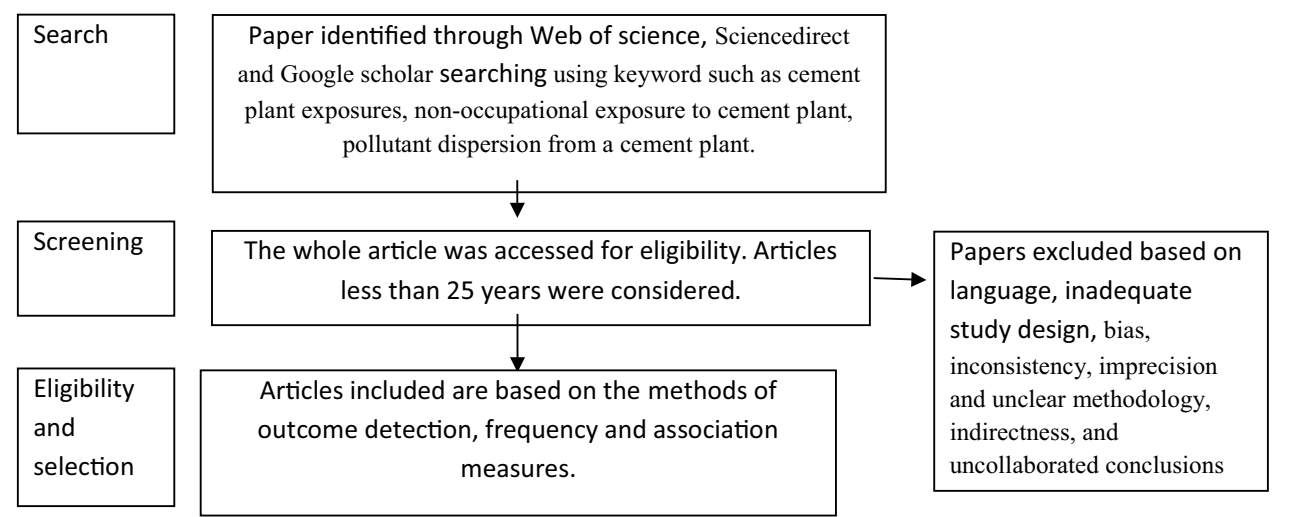


The absence or presence of dust control technology also affects the PM emitted. When dust control technology is not in use, 24 and $7 \%$ of the released PM are less than 10 and $2.5 \mu \mathrm{m}$ respectively for wet process kiln. While in dry process kiln, 42 and $18 \%$ of the PM are less than 10 and $2.5 \mu \mathrm{m}$ respectively. The application of dust control system results in $85 \%$ of the particle released less than $10 \mu \mathrm{m}$ in diameter for both wet and dry process. However, the use of bag houses in the dry process, results in $45 \%$ of the escaped particles to be less than $2.5 \mu \mathrm{m}$. Use of bag filter among others has successfully reduced PM emitted as different research has indicated removal efficiency of about $99 \%$ [38]. The use of dust control system were observed by $[2,21-51]$ as showed in Table 1 below to prevent the emission of up $31-99 \%$ of these elements.

Mlakar et al. [52], estimated that at a particular cement plant in western part of Slovenia, injected $27 \mathrm{~kg}$ of mercury into its system during a production year through mostly the raw material $(16.1 \mathrm{~kg} / \mathrm{yr})$, and fuel accounting for $10.9 \mathrm{~kg} / \mathrm{yr}$ in 2006 . As the production capacity is increased or more plants are built, the use of more raw materials and coal as fuel would increase the amount emitted each year. This trend has being observed in China, as an increase in production has led to an increase in the amount of mercury emitted [21]. The utilization of various materials during production such as sludge at percentages higher the $15 \%$ affects the composition of the PM [53]. The use of materials such as waste oil, sewage sludge, tyre and refuse derived fuel could increase the level of heavy metals released to the atmosphere. Naturally, the raw materials used in production of cement process different levels of various elements, but the addition of alternative fuel significantly increased the amount.

The use of tyre as supplementary fuel has resulted in the release of class I and II metals. Such metal recorded include $\mathrm{N}, \mathrm{Pb}, \mathrm{Zn}$. However, several studies have documented scenarios where the emission of heavy metals with alternative fuels has no significant impact. In such scenarios, the fuel replacement ratio, waste preparation, reducing or oxidising atmosphere and feeding point, is pivot. Some scenarios have favoured some metal compared to other metals. Different alternative fuels have different mix ratio with traditional fuel, in most cases the composition of the alternative raw material will determine its application and transfer factor [54]. However, although the input of metal elements are increased though this alternative fuel source (as shown in Table 2), the consensus remains that the increase are still not significant [38]. With a good mix ratio achieved on a plant to plant basis, depending on the type of fuel waste available within the plant environ, the use of alternative fuel leads to reduction in pollutant emission and natural resources as well as cost reduction in addition to substantiality [55].

Some of these pollutants are subject to bio-accumulation and undergo long-distance transport. The mechanism of absorption include digestive route, respiratory route
Table 1 Input rates of heavy metals and emission through dust control system observed by [38]

Table 2 Heavy metal present in alternative fuel sources

\begin{tabular}{lcclllll}
\hline & $\mathrm{As}\left(\mathrm{kg} \mathrm{h}^{-1}\right)$ & $\mathrm{Cd}\left(\mathrm{kg} \mathrm{h}^{-1}\right)$ & $\mathrm{Cr}\left(\mathrm{kg} \mathrm{h}^{-1}\right)$ & $\mathrm{Cu}\left(\mathrm{kg} \mathrm{h}^{-1}\right)$ & $\mathrm{Ni}\left(\mathrm{kg} \mathrm{h}^{-1}\right)$ & ${\mathrm{Pb}\left(\mathrm{kg} \mathrm{h}^{-1}\right)}^{\mathrm{Zn}\left(\mathrm{kg} \mathrm{h}^{-1}\right)}$ \\
\hline Input & 29.99 & 15.7 & 5.7 & 2.07 & 8.84 & 31.5 & 11.8 \\
Emitted & 0.02 & 0.008 & 0.003 & 0.001 & 0.003 & 0.019 & 0.007 \\
\hline
\end{tabular}

\begin{tabular}{|c|c|c|c|c|c|c|}
\hline & RDF & Coal & Cutting oil & Sludge & Tyre & $\begin{array}{l}\text { Coalm- } \\
\text { ine } \\
\text { wastes }\end{array}$ \\
\hline $\mathrm{Sb}$ & $\mathrm{Y}$ & & & & & \\
\hline $\mathrm{Mn}$ & & & & & $\mathrm{Y}$ & $\mathrm{Y}$ \\
\hline $\mathrm{Hg}$ & $\mathrm{Y}$ & Y & $\mathrm{Y}$ & $\mathrm{Y}$ & & $\mathrm{Y}$ \\
\hline $\mathrm{Cd}$ & $\mathrm{Y}$ & Y & & $Y$ & & $Y$ \\
\hline As & $\mathrm{Y}$ & & & & & $Y$ \\
\hline $\mathrm{Pb}$ & $\mathrm{Y}$ & & & & & $Y$ \\
\hline $\mathrm{Cu}$ & $\mathrm{Y}$ & & $\mathrm{Y}$ & $Y$ & $Y$ & $Y$ \\
\hline $\mathrm{Cr}$ & $\mathrm{Y}$ & & $\mathrm{Y}$ & $\mathrm{Y}$ & & $Y$ \\
\hline $\mathrm{Zn}$ & $\mathrm{Y}$ & & & $Y$ & $\mathrm{Y}$ & $\mathrm{Y}$ \\
\hline Co & & Y & $\mathrm{Y}$ & & & $\mathrm{Y}$ \\
\hline $\mathrm{Ti}$ & & $Y$ & & & $Y$ & $\mathrm{Y}$ \\
\hline $\mathrm{Ni}$ & & & $Y$ & & $Y$ & $\mathrm{Y}$ \\
\hline $\mathrm{Pb}$ & & & $\mathrm{Y}$ & $\mathrm{Y}$ & $Y$ & $\mathrm{Y}$ \\
\hline
\end{tabular}


and pores of skin $[5,41]$. There are three classes of HMs toxicity as showed in the Table 3 based on their toxicity and harmful effects. Manganese (Mn), strontium (Sr), Lead $(\mathrm{Pb})$, Titanium ( $\mathrm{Ti})$, Vanadium $(\mathrm{V})$ and Zinc $(\mathrm{Zn})$ have been observed in the raw meal. Other such as Arsenic (As), Lead $(\mathrm{Pb})$, Manganese $(\mathrm{Mn})$ and $\mathrm{Zinc}(\mathrm{Zn})$ are from in coalmine waste. $V$ is from pet coke and $Z n$ from Scrap tire. High levels of Mercury $(\mathrm{Hg})$ are detected with the use of tires, fly ash from coal-fired power plant and sewage sludge as supplemental fuel during production as indicated in Table 2 $[35,38]$. Different values of $\mathrm{Hg}$ have been reported from various parts of the world. This concentration ranges from 0.001 to $0.062 \mathrm{mg} \mathrm{Nm}^{-3}$ [7], estimate that 15 tonnes of $\mathrm{Hg}$ are emitted to the environment yearly in US alone.

From a comparative assessment, higher amounts of $\mathrm{Cu}, \mathrm{Mn}, \mathrm{Cr}$ and Ni were reported in the US than in Nigeria [7]. The concentration of $\mathrm{Ni}$ measured in US was higher than the average published value and was twice the value obtained in Nigeria. Also, $\mathrm{Cu}, \mathrm{Mn}$ and $\mathrm{Cr}$ were 10, 7 and 13.4 times higher than Nigeria cement dust. But the Cadmium concentration in Nigeria cement dust is between 9.8 and 11 times the US cement dust while $\mathrm{Hg}$ and $\mathrm{Pb}$ were also higher in Nigeria cement dust. Other metals include $\mathrm{Ca}, \mathrm{Zn}$ and Fe.

Polychlorinated dibenzo- $p$-dioxins and dibenzofurans (PCDD/Fs), also referred to as dioxins are a group of 210 chlorinated organic compounds [56]. According to several reports such as [57], only seventeen PCDD/Fs congeners with chlorine substitution in 2, 3, 7, 8 positions are harmful to humans. Reports especially historical inventory such as [58] put cement plants release of PCDD/Fs to about $10.3 \%$ of total emissions. The formations of PCDD/Fs are dependent on kiln type, feeding fuel, raw material, air pollution control devices and combustion conditions. Multiple researchers have shown that PCDD/F emissions from alternative fuels are not higher than using conventional fuel [59].

Table 3 Heavy metal classification

\begin{tabular}{lll}
\hline Class I & Class II & Class III \\
\hline Cadmium (Cd) & Arsenic (As) & Lead (Pb) \\
Mercury (Hg) & Cobalt (Co) & Chromium (Cr) \\
Titanium (Ti) & Nickel (Ni) & Copper (Cu) \\
& Selenium (Se) & Platinum (Pt) \\
& Tellurium (Te) & Vanadium (V) \\
& Zinc (Zn) & Tin (Sn) \\
& & Palladium (Pd) \\
& & Antimony (Sb) \\
& & Manganese (Mn) \\
& & Rhodium (Rh) \\
& &
\end{tabular}

\section{Effects on human}

Different studies as listed in Table 4 shows various studies that have been examined to assess the impact of cement dust on humans. Different study design such as cross section, case study, ecologic and retrospective cohort focused on children, adults and workers were examined. Association between cement dust and various types of cancer, mortality, respiratory and cardiovascular disease were observed.

Several reports have concluded that PCDD/F emissions do not pose a significant threat to humans health [68]. This does not mean it cannot be, but generally, its emission is within limits. The possible effects on humans health include endocrine disruption, and carcinogenicity [36]. The inhalation cancer risk was revealed to be between $5.0 \times 10^{-11}$ and $2.0 \times 10^{-8}$ while that of oral carcinogenic risk is between $1.8 \times 10^{-8}$ and $7.6 \times 10^{-8}$ [60]. The incremental lifetime risk of cancer for people living close to a plant will be 0.03 . Silica dust causes silicosis and fatal lung diseases. The presence of chromium compounds in cement dust might lead to cancer [23].

Several researchers have argued that pollutants might have unknown consequences on the people and the environment [69]. Their reaction within the human body could be novel. With various sizes, absorption into the body might be unpreventable.

Research has also shown that cement dust causes morbidity, chronic obstructive pulmonary, preterm delivery, psychasthenia, endocrine disruption, and infertility. The severity is dependent on the duration of exposure, concentration and element constituent of the dust, and individual sensitivity [70-74].

The first victims are usually the factory workers. Several studies revealed that factory workers suffered from respiratory diseases, and it is more prevalent among the packing section workers [29]. Dermatitis, caused by hexavalent chromium $\left(\mathrm{Cr}^{6+}\right)$ in cement are observed within the workforce [61]. High level of Cd observed in the Nigeria cement dust, constitute a high health risk as its average half-life in a human body is between 4 and 19 years [7]. Long-term exposure might lead to renal tubular dysfunction. It also affects the respiratory tract and immune system modulation and reduces the phagocytic activity of polymorphonuclear neutrophils (PMN).

Several research works, including Emmanuel and Alabi [74], indicating a higher risk of chronic kidney disease and end-stage renal disease. This research reported showed that cement factory workers have a higher white blood cell (WBC) and lower red blood cell. This is suggested to be due to the response of the body to irritation on the body. Also, it might be due to increase in 


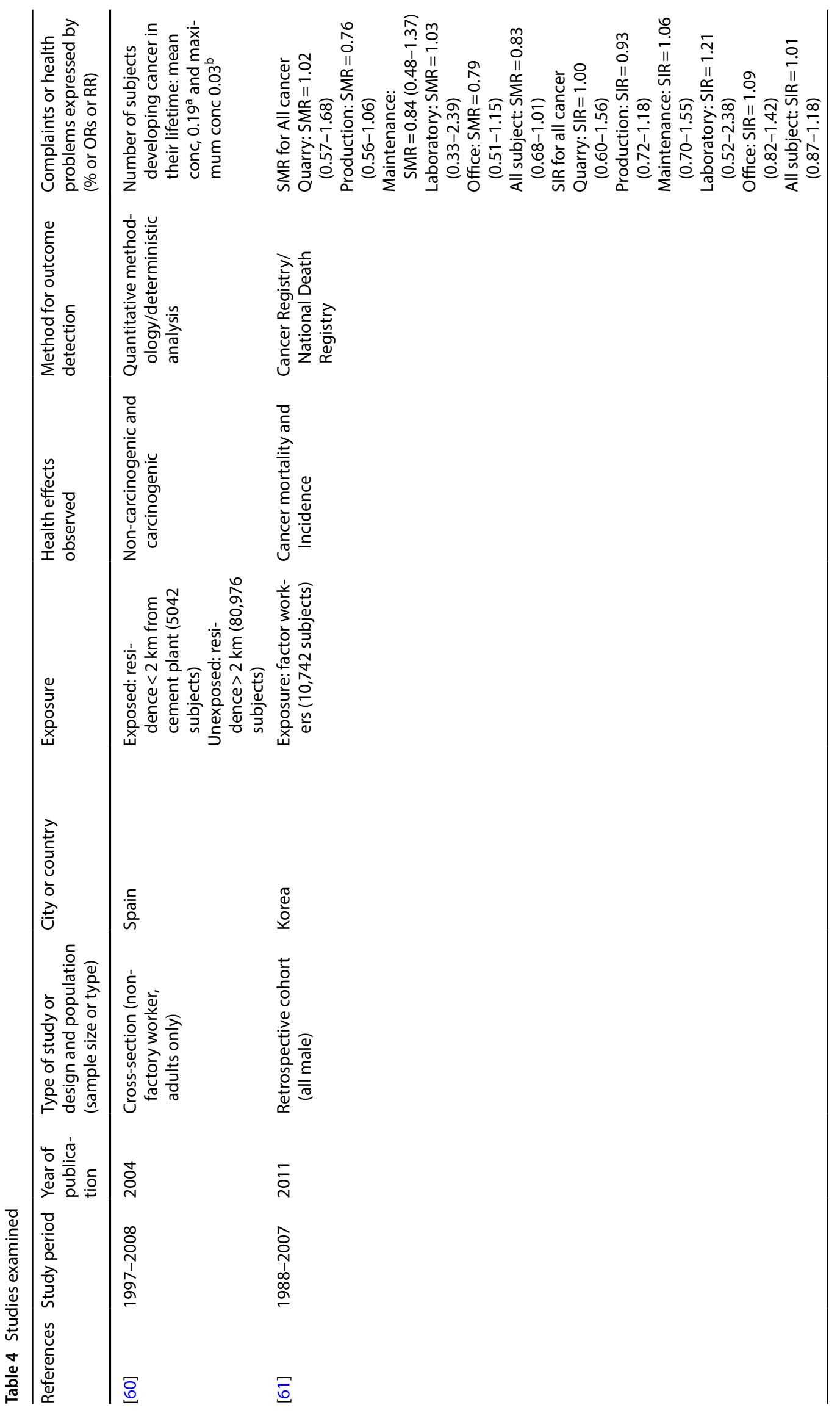




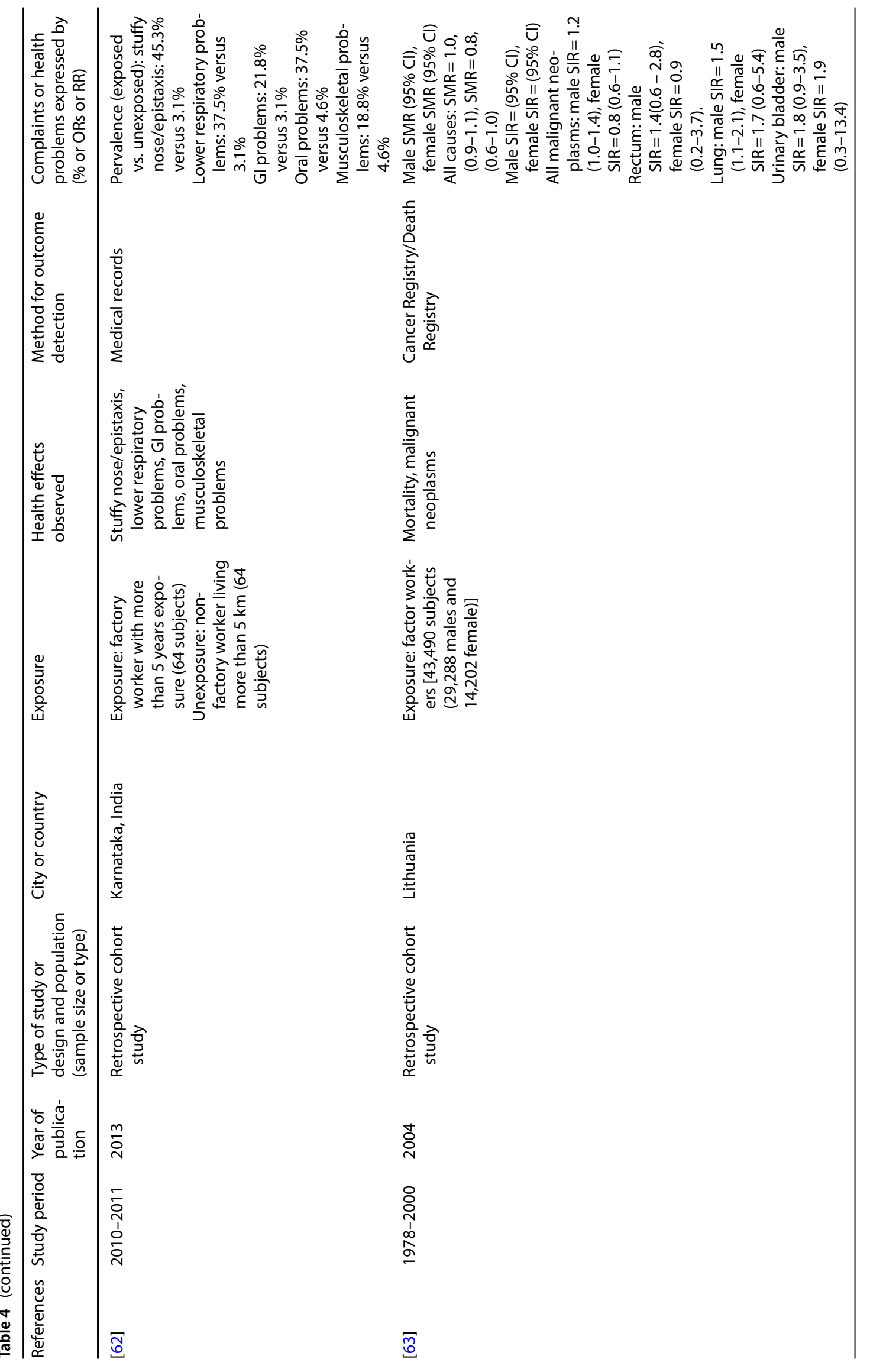

SN Applied Sciences

a SPRINGER NATURE journal 


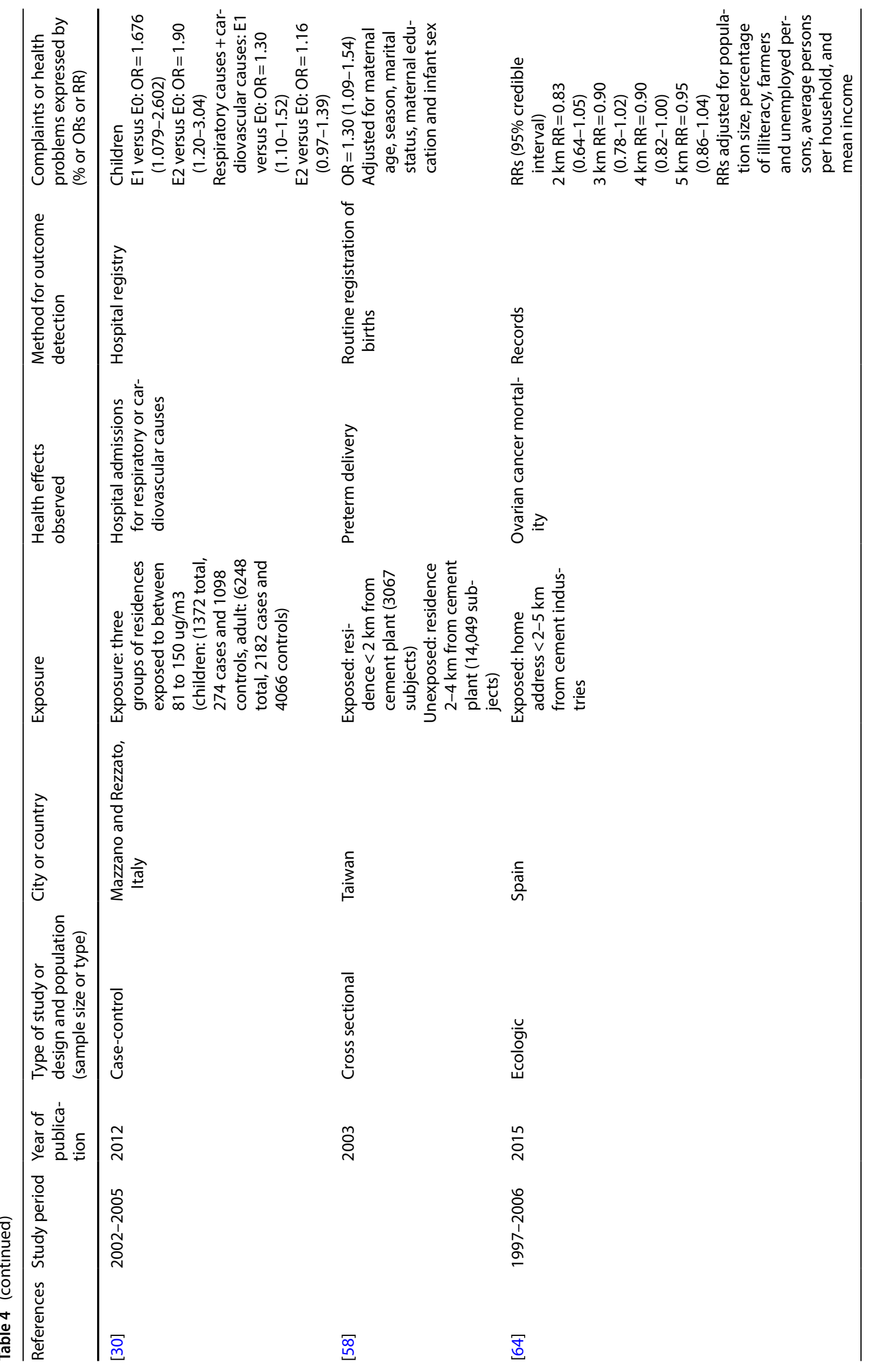




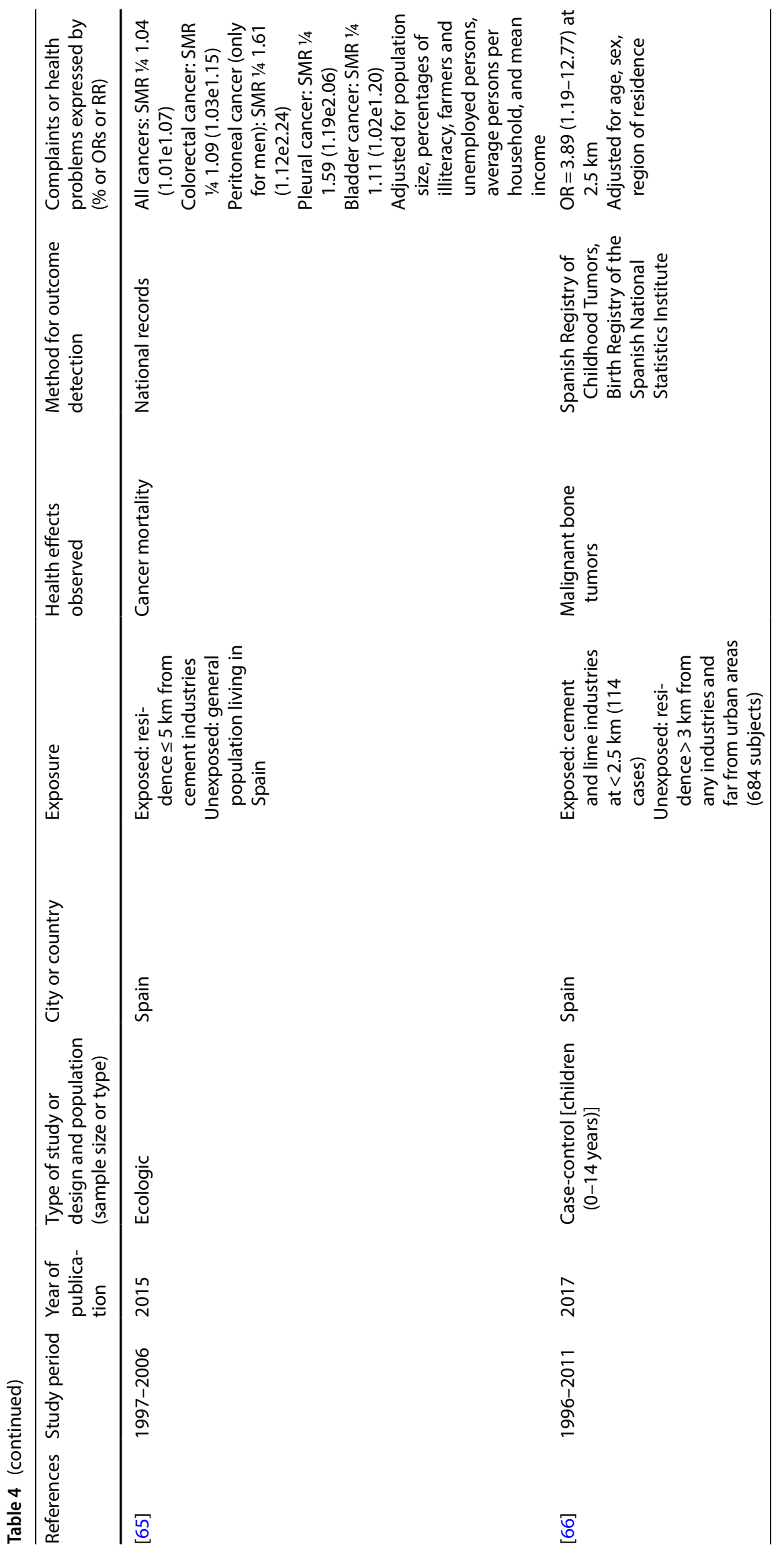

SN Applied Sciences

a SPRINGER NATURE journal 


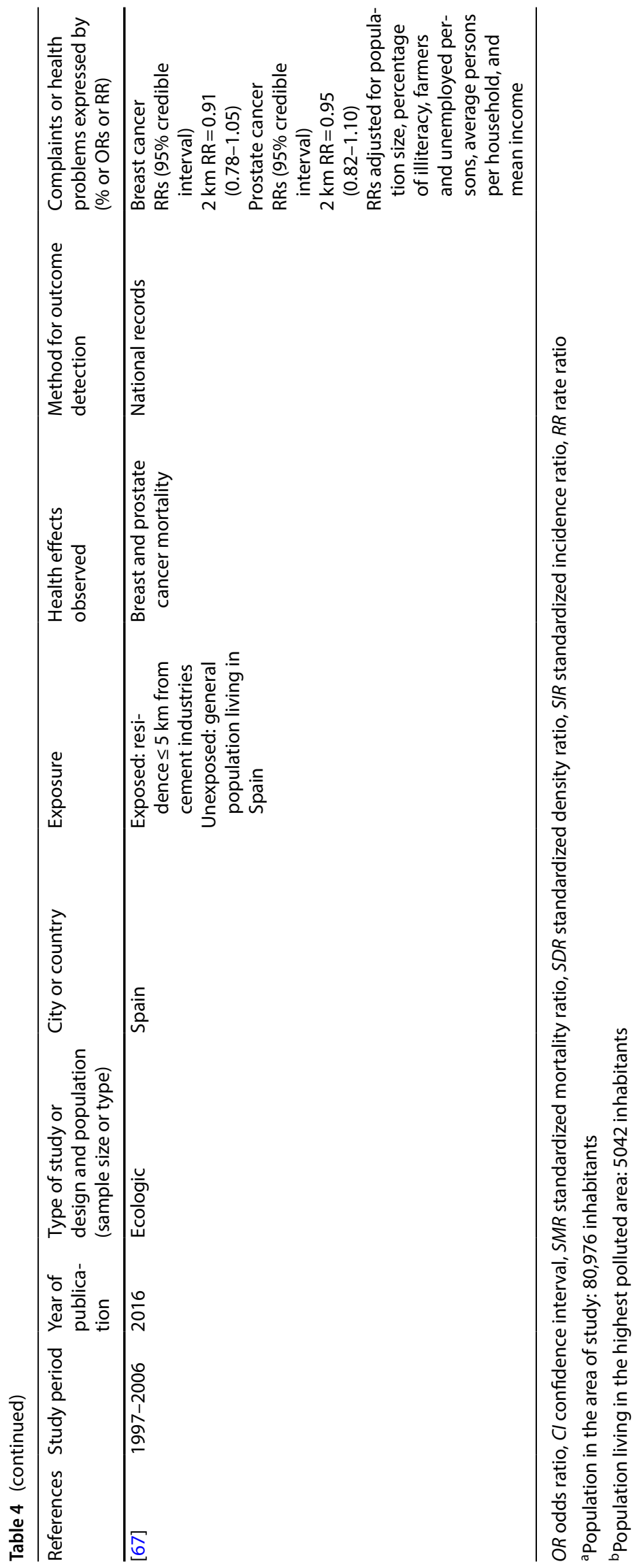


Lymphocytes count and reduction in monocytes count. The increase in platelets was observed to be due to stress response. Other research reported that cement dust results in a reduction of haemoglobin concentration as well as packed cell volume, which might indicate anaemic condition [74]. Diverse researchers linked the increase in WBC and RBC to a harmful effect on bone marrow.

Different studies such as Oyinloye [28], Yang et al. [62] and Smailyte et al. [63], have used different methods to determine the relative risk or standardised incidence ratios (SIR) of worker to different risks workers are exposed to. However, qualitative analysis was not carried out to understand whether or not the risks calculated is mainly based on cement plant emission or due to addition of other factors such as traffic or other industries in the area.

Different research has indicated that the lung cancer relative risk associated with $\mathrm{PM}$ exposure ranges from 3.36 to 0.91 from different variables considered. The study also showed DNA damages, micronuclei sister chromatid exchange, swingle-strand breaks and oxidative DNA damage. Toxicological studies in vivo and in vitro showed that PM have the ability to generate continuously high reactive oxygen species (ROS), which aids the genotoxic and cytotoxic mechanisms of PM [72].

Ogunbileje et al. [7, 34] indicated that the primary effect of $\mathrm{Hg}$ is its accumulation in the kidney and its disruption of activities within the liver. Hg's long term effects include debilitating diseases which include neurodegeneration (Alzheimer's disease and Autism). Continuous exposure of workers to $M n$ results in lung irritation and lung injury. This is observed as cough, pneumonitis, and bronchitis, which is easily associated with cement factory workers.

Oguntoke et al. [32], reported that $31 \%$ of the examined workers reported dermatitis, rashes and eczema. These complaints were followed by catarrh, cold and coughs. The engineers reported dermatitis and eczema more. Production workers and quarry workers reported respiratory tract infection [34]. Also, conjunctivitis and furunculosis were reported by production workers.

A study by Bertoldi et al. [30] discovered that children (also by Marcon et al. [75]) were more negatively affected by cement plant air pollution. It was discovered that if the concentration of $\mathrm{NO}_{\mathrm{X}}$ is lower than $110 \mu \mathrm{g} / \mathrm{m}^{3}$, the child hospital admission rate would be reduced by $38 \%$. The second group affected mostly, were male groups as more men were observed to work in the open. But Adeniran et al. [4] and Yang et al. [46] revealed that dust measured from houses at some distance from a cement plant was well beyond the WHO standard.

Research has not specifically linked certain diseases with cement dust or air pollutant from cement plants. Researchers are observing an increase in risk when living near cement plants. García-pérez et al. [64], associated risk increase of ovarian cancer mortality with living close to cement plants. García-pérez et al. [65], linked living near a cement plant to increase in the chance of colon-rectum cancer for both men and women. Also, higher risk for having gallbladder, peritoneum, pleura and bladder cancer were noticed. It observed that men are the most affected mainly due to their occupation.

The link between bone tumours in children and living near industries such as cement plant was observed by [66, 76]. García-Pérez et al. [67], observed people living near a cement plant would have higher risks of breast and prostate cancer mortality. Yang et al. [46], indicated that cement dust might contribute to preterm delivery, but there are other factors to consider. Also, Marcon et al. [75], observed that children's exposure to PM causes acute adverse health effects, with more effects on the long term.

\section{Effects on plant and aquatic life}

Humans are not the only ones affected. Different research have shown that flora and fauna are also affected. Rai [77], stated that effects on plants (injury) are either acute or chronic. Acute injury results from short exposure to high concentration while chronic injury occurs due to exposure to low concentration for prolonged periods. Effects on plants vary from plant growth to productivity [78]. The effect occurs from reduced light for photosynthesis, increase in leaf temperature and mineral availability, alteration of plant enzymes, and reduction in leaf size, number, and foliar area (Table 5).

All organisms' need certain elements in certain proportions, large doses are mostly detrimental. Negative effects observed include oxidative stress, damage of cell membranes, photosynthetic apparatus and photosystem, excessive production of reactive compounds, protein cleavage as well as chlorophyll biosynthesis. Cells have developed different mechanisms such as the enzymatic and non-enzymatic mechanism to cope with the various effects. They include catalase (CAT), peroxidase (POX) and superoxide dismutase (SOD) $[37,79]$. The activity of CAT, SOD, and POX as varied with different plants, especially when close to the pollution source.

Erdal and Demirtas [37] revealed that $\mathrm{H}_{2} \mathrm{O}_{2}$ levels were higher in plants within the polluted area. Malondialdehyde (MDA) was observed to increase as $\mathrm{H}_{2} \mathrm{O}_{2}$ increased. This is attributed to cell damage. Kumar et al. [81] reported that lives around the cement plant suffer chlorosis and necrosis. Also, Salih et al. [31] revealed that the levels of $\mathrm{P}$ (phosphorus), $\mathrm{K}$ (potassium), $\mathrm{S}$ (sulfur), and $\mathrm{Cl}$ (chlorine) have been reported to be high around factories while $\mathrm{Ca}$ (Calcium) and Fe (Iron) elements reduced. This result 


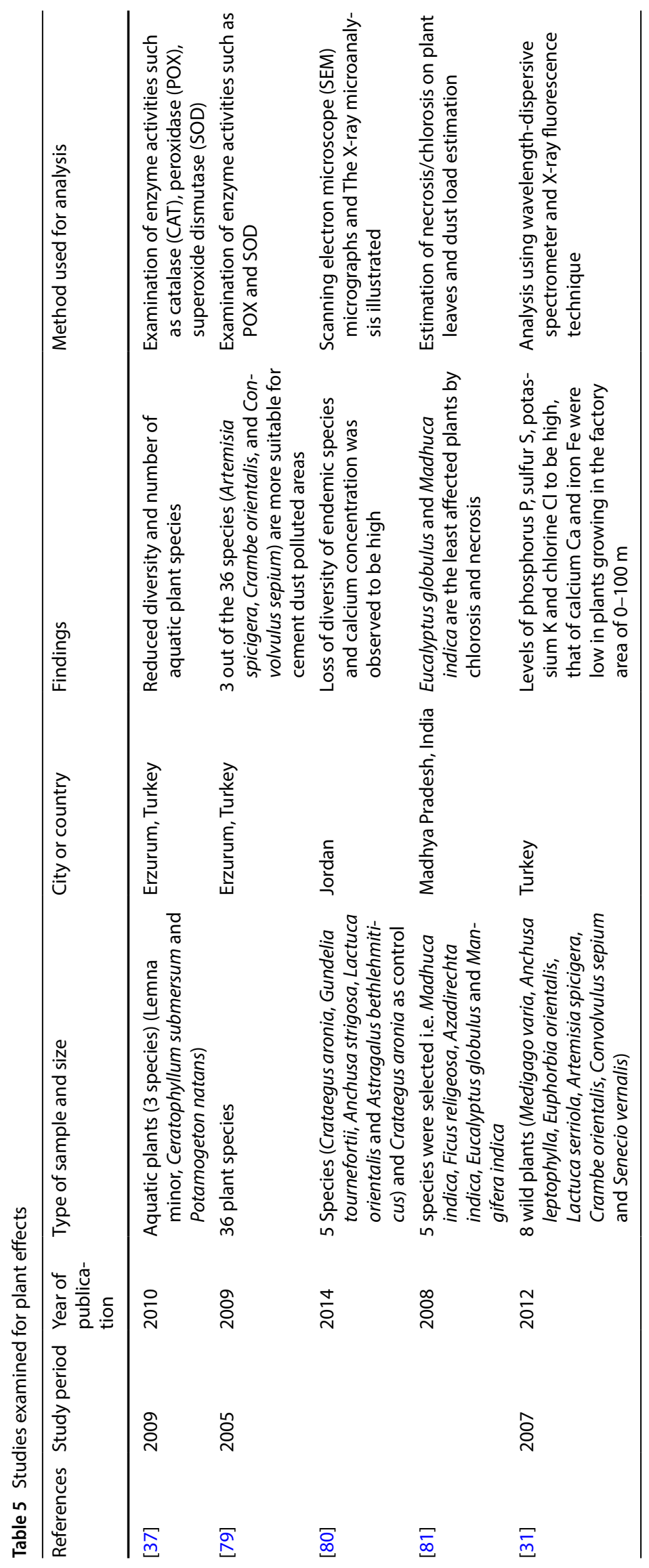


in stunted growth, leaf resetting, chlorosis, brown-gray necrosis, reduced long term yield. All these elements are required in the plant at acceptable levels, but the constant emission of these elements affects the ability of the plant to internally process and survive on these elements. Basically, plants require $0.1-0.5 \% \mathrm{~S}, 0.3-0.5 \% \mathrm{P}$ and $2-5 \% \mathrm{~K}$ of the plant dry weight. They also require $0.20-0.40 \mathrm{mg} / \mathrm{g}$ of $\mathrm{Cl}$ dry weight and $100 \mathrm{ppm}$ Fe of dry matter. Excess or reduction of these elements amounts on plant significantly affects the growth and survival of the plant.

Oran and Zahra [80] observed that cement dust affects local plant species and diversity. Effects of cement dust were observed in beaches in which it was preventing the egg hatching of sea turtles [82]. It discovered that it prevented oxygen and carbon dioxide diffusion.

Alternative fuel sources contribute to air pollution, but the effect and risk associated with its pollutant do not increase diseases among residential areas near the plant [41]. The developments of energy efficiency and $\mathrm{CO}_{2}$ emission reduction models and scenarios have shown that the number of air pollutant would reduce. Zhang et al. and Zhang et al. [14, 83], and project that $\mathrm{PM}, \mathrm{SO}_{2}$, and $\mathrm{NO}_{\mathrm{X}}$ would be reduced by $2-5 \%, 10-25 \%$ and $8-20 \%$ by the year 2030. In most cases, only one or two elements are above specified standards $[2,40]$.

\section{Studies needed in developing regions}

The pollution of the cement industry has never been denied, but the extent to which it affects the environment is still unknown. The effects of cement kiln dust from different cement plant on human health or the environment vary based on individual plant characteristics and operation processes. The presence of other industries or even traffic significantly affects the estimation of the effects of these pollutants on human health. In most studies where a particular contaminant is high, it is an individual plant problem.

Therefore, studies of various cement plants at different location across all regions should be carried out locally, since each cement emission is specific. Raw materials used in production in developing countries should be investigated to understand their contribution to pollutant generation and the amount emitted through the production process. Also, there is a need to create real time air quality stations near a cement plant, especially in developing countries where little or no data is available.

Most studies from Africa failed to mention the alternative fuel used as well as the dust control technology in place, its efficiency and its effects on the characteristics of emitted pollutants. Also, the concentration of pollutant released into the atmosphere was not effectively measured or examined. Dispersion modelling is not being carried out to understand the effects of different pollutants have on people living close to the plant. However, some studies from Africa have shed light on the concentration of heavy metals present in cement kiln dust.

More studies into the impact of cement dust needs to be carried out in developing counties. Present studies from developing countries focus more on occupational studies. Those studies are achieved through interviews of what sickness workers regularly experience. In most cases, the numbers of subjects are small, and are biased. More studies using ecologic, retrospective cohort study or casecontrol study design needs to be carried out.

Since bush or wood burning contributes largely to PM generation in Africa, research into the characterisation of such PM from these activities should be carried out. The results of such analysis should be compared with the PM characteristics from cement plants.

\section{Conclusion}

Cement production pollutants cannot be ultimately held responsible for cancer cases. There is more than enough evidence to associate it with respiratory diseases, skin and eye irritation. There are so many factors to consider, and the role of cement pollution is still unknown. The extent to which it contributes will be more obvious as more researches are done in this regard. Retired or long servicing workers should be examined for various health implications under retrospective cohort study. Their continuous exposure over the years makes them valuable subjects.

Until the connection is made and appropriate amendments carried out, standard air pollution control measures must be enforced. Some plants where air quality monitoring is low have recorded more environmental effects. Recent improvements in the invention and production processes have resulted in the reduction of pollutant emission to the atmosphere. The reduction method might be finding an alternative to cement as a product. The amount of pollutants released even with the best methods is dependent on the amount of cement produced.

It is recommended that more routine air quality assessments carried out by different stakeholders. More research ecologic and Retrospective cohort study to understand effects of cement exposure needs to be done. Adherence to international standards on dust control technologies must be encouraged and monitored. The best method for workers is the use of protective personal equipment, which is not sometimes used by them even when freely provided. For resident, the best option is living more than $5 \mathrm{~km}$ away from the plant. 


\section{Compliance with ethical standards}

Conflict of interest The authors declare that they have no conflict of interest.

\section{References}

1. Karagulian et al (2015) Contributions to cities' ambient particulate matter (PM): a systematic review of local source contributions at global level. Atmos Environ 120:475-483

2. Sánchez-Soberón et al (2015) Main components and human health risks assessment of PM 10, PM 2.5, and PM 1 in two areas influenced by cement plants. Atmos Environ 120:109-116

3. Hua et al (2016) Atmospheric emission inventory of hazardous air pollutants from China's cement plants: temporal trends, spatial variation characteristics and scenario projections. Atmos Environ 128:1-9

4. Adeniran JA, Yusuf RO, Fakinle BS, Sonibare JA (2018) Air quality assessment and modelling of pollutants emission from a major cement plant complex in Nigeria. Atmos Pollut Res 10:257-266

5. Arfala Y, Douch J, Assabbane A, Kaaouachi K, Tian H, Hamdani M (2018) Assessment of heavy metals released into the air from the cement kilns co-burning waste: case of Oujda cement manufacturing (Northeast Morocco). Sustain Environ Res 28:1-11

6. Shen et al (2017) Cement industry of China: driving force, environment impact and sustainable development. Renew Sustain Energy Rev 75:618-628

7. Ogunbileje JO, Sadagoparamanujam VM, Anetor Jl, Farombi O, Akinosun OM, Okorodudu AO (2013) Lead, mercury, cadmium, chromium, nickel, copper, zinc, calcium, iron, manganese and chromium (VI) levels in Nigeria and United States of America cement dust. Chemosphere 90:2743-2749

8. Song D, Yang J, Chen B, Hayat T, Alsaedi A (2016) Life-cycle environmental impact analysis of a typical cement production chain. Appl Energy 164:916-923

9. Cai B, Wang J, He J, Geng Y (2016) Evaluating $\mathrm{CO}_{2}$ emission performance in China's cement industry: an enterprise perspective. Appl Energy 166:191-200

10. Chen W, Hong J, Xu C (2015) Pollutants generated by cement production in China, their impacts, and the potential for environmental improvement. J Clean Prod 103:61-69

11. L. Africa, "Lafarge Africa”. https://www.lafarge.com.ng/lafargenigeria. Retrieved 21 May 2019

12. Chen C, Habert G, Bouzidi Y, Jullien A (2010) Environmental impact of cement production: detail of the different processes and cement plant variability evaluation. J Clean Prod 18:478-485

13. Shen W, Cao L, Li Q, Zhang W, Wang G, Li C (2015) Quantifying $\mathrm{CO}_{2}$ emissions from China's cement industry. Renew Sustain Energy Rev 50:1004-1012

14. Zhang S, Worrell E, Crijns-Graus W (2015) Evaluating co-benefits of energy efficiency and air pollution abatement in China's cement industry. Appl Energy 147:192-213

15. Benhelal E, Zahedi G, Shamsaei E, Bahadori A (2013) Global strategies and potentials to curb $\mathrm{CO}_{2}$ emissions in cement industry. J Clean Prod 51:142-161

16. Jun L, Zhang S, Wagner F (2018) Exploring the driving forces of energy consumption and environmental pollution in China's cement industry at the provincial level. J Clean Prod J 4184:274-285

17. Guimarães AG, Vaz-Fernandes P, Ramos MR, Martinho AP (2018) Co-processing of hazardous waste: the perception of workers regarding sustainability and health issues in a Brazilian cement company. J Clean Prod 186:313-324

18. Matar W, Elshurafa AM (2017) Striking a balance between profit and carbon dioxide emissions in the Saudi cement industry. Int J Greenh Gas Control 61:111-123

19. Zhang S, Ren H, Zhou W, Yu Y, Chen C (2018) Assessing air pollution abatement co-benefits of energy efficiency improvement in cement industry: a city level analysis. J Clean Prod 185:761-771

20. Won JH, Lee TG (2012) Estimation of total annual mercury emissions from cement manufacturing facilities in Korea. Atmos Environ 62:265-271

21. Wang F, Wang S, Zhang L, Yang H, Wu Q, Hao J (2016) Characteristics of mercury cycling in the cement production process. $J$ Hazard Mater 302:27-35

22. Zhang et al (2019) Linking the $\mathrm{SO}_{2}$ emission of cement plants to the sulfur characteristics of their limestones: a study of 80 NSP cement lines in China. J Clean Prod 220:200-211

23. Abdul-Wahab SA (2006) Impact of fugitive dust emissions from cement plants on nearby communities. Ecol Modell 195:338-348

24. Adetayo J, Sunday B, Ademola J (2019) Air quality assessment and modelling of pollutants emission from a major cement plant complex in Nigeria. Atmos Pollut Res 10:257-266

25. Kim et al (2015) Ventilation impairment of residents around a cement plant. Ann Occup Environ Med 27:3

26. Lee et al (2016) Emphysema prevalence related air pollution caused by a cement plant. Ann Occup Environ Med 28:4-11

27. Cement H (2012) Hanson Cement investigation, issue 5. Retrieved from www.publichealthwales.org/hansoncementinv estigation

28. Oyinloye MA (2015) Environmental pollution and health risks of residents living near Ewekoro Cement Factory, Ewekoro, Nigeria. World Acad Sci Eng Technol Int J Archit Environ Eng 9:108-114

29. Chukwu MN, Ubosi NI (2016) Impact of cement dust pollution on respiratory systems of Lafarge cement workers, Ewekoro, Ogun State, Nigeria. Glob J Pure Appl Sci 22:1-5

30. Bertoldi et al (2012) Health effects for the population living near a cement plant: an epidemiological assessment. Environ Int 41:1-7

31. Mutlu S, Atici O, Gülen Y (2013) Cement dust pollution induces toxicity or deficiency of some essential elements in wild plants growing around a cement factory. Toxicol Ind Health 29:474-480

32. Oguntoke $\mathrm{O}$, Awanu $A E$, Annegarn HJ (2012) Impact of cement factory operations on air quality and human health in Ewekoro Local Government Area, South-Western Nigeria. Int J Environ Stud 69:934-945

33. Rovira J, Mari M, Nadal M, Schuhmacher M, Domingo JL (2011) Levels of metals and PCDD/Fs in the vicinity of a cement plant: assessment of human health risks. J Environ Sci Health Part A Toxic/Hazard Subst Environ Eng 46:1075-1084

34. Singh VS, Pandey DN (2011) Human health risk due to cement dust exposure policy-brief climate change and CDM cell. Rajasthan State-Pollution Control Board, Jaipur, pp 1-19

35. Ziadat AH, Batarseh M, El-Hasan T, Berdanie BW, Jiries A (2006) Chemical and mineralogical characteristics of dry deposition in the surrounding of a cement factory in Jordan. Environ Forensics $7: 169-174$

36. Zhao et al (2017) Evaluation of dioxins and dioxin-like compounds from a cement plant using carbide slag from chlor-alkali industry as the major raw material. J Hazard Mater 330:135-141

37. Erdal S, Demirtas A (2010) Effects of cement flue dust from a cement factory on stress parameters and diversity of aquatic plants. Toxicol Ind Health 26:339-343

38. Gupta RK, Majumdar D, Trivedi JV, Bhanarkar AD (2012) Particulate matter and elemental emissions from a cement kiln. Fuel Process Technol 104:343-351 
39. Mehraj SS, Bhat GA, Balkhi HM, Gul T (2013) Health risks for population living in the neighborhood of a cement factory. Afr J Environ Sci Technol 7:1044-1052

40. Rovira J, Mari M, Schuhmacher M, Nadal M, Domingo JL (2011) Monitoring environmental pollutants in the vicinity of a cement plant: a temporal study. Arch Environ Contam Toxicol 60:372-384

41. Schuhmacher M, Nadal M, Domingo JL (2009) Environmental monitoring of PCDD/Fs and metals in the vicinity of a cement plant after using sewage sludge as a secondary fuel. Chemosphere 74:1502-1508

42. Stajanča M, Eštoková A (2012) Environmental impacts of cement production. Tech Univ Kosice Civ Eng Fac Inst Archit Eng 737:296-302

43. Sidhu S, Kasti N, Edwards P, Dellinger B (2001) Hazardous air pollutants formation from reactions of raw meal organics in cement kilns. Chemosphere 42(499-506):2001

44. Wang Y, Zhu Q, Geng Y (2013) Trajectory and driving factors for GHG emissions in the Chinese cement industry. J Clean Prod $53: 252-260$

45. Parithielamvazhuthi R (2015) Analysis of air pollutant emission and control system in cement industries around Ariyalur District. Int J Sci Res 4:1716-1719

46. Yang et al (2003) Preterm delivery among people living around Portland cement plants. Environ Res 92:64-68

47. Cassee FR, Héroux ME, Gerlofs-Nijland ME, Kelly FJ (2013) Particulate matter beyond mass: recent health evidence on the role of fractions, chemical constituents and sources of emission. Inhal Toxicol 25:802-812

48. Ohlson et al (2010) Inflammatory markers and exposure to occupational air pollutants. Inhal Toxicol 22:1083-1090

49. Schlesinger RB (2007) The health impact of common inorganic components of fine particulate matter $\left(\mathrm{PM}_{2.5}\right)$ in ambient air: a critical review. Inhal Toxicol 19:811-832

50. Davidson Cl, Phalen RF, Solomon PA (2005) Airborne particulate matter and human health: a review. Aerosol Sci Technol 39:737-749

51. Rovira J, Sierra J, Nadal M, Schuhmacher M, Domingo JL (2018) Main components of PM10 in an area influenced by a cement plant in Catalonia, Spain: seasonal and daily variations. Environ Res 165:201-209

52. Mlakar et al (2010) Mercury species, mass flows and processes in a cement plant. Fuel 89:1936-1945

53. Shih P-H, Chang J-E, Lu H-C, Chiang L-C (2005) Reuse of heavy metal-containing sludges in cement production. Cem Concr Res 35:2110-2115

54. Genon G, Brizio E (2008) Perspectives and limits for cement kilns as a destination for RDF. Waste Manag 28:2375-2385

55. Kara M (2012) Environmental and economic advantages associated with the use of RDF in cement kilns. Resour Conserv Recycl 68:21-28

56. Zhou T, Bo X, Qu J, Wang L, Zhou J, Li S (2019) Characteristics of PCDD/Fs and metals in surface soil around an iron and steel plant in North China Plain. Chemosphere 216:413-418

57. Ngo TH, Tsou HH, Chen YF, Chen YW, Chi KH (2018) Sources identification of PCDD/Fs in soil and atmospheric deposition in Taiwan. Chemosphere 208:374-381

58. Chen CM (2004) The emission inventory of PCDD/PCDF in Taiwan. Chemosphere 54:1413-1420

59. Zou L, Ni Y, Gao Y, Tang F, Jin J, Chen J (2018) Spatial variation of PCDD/F and PCB emissions and their composition profiles in stack flue gas from the typical cement plants in China. Chemosphere 195:491-497

60. Schuhmacher M, Domingo JL, Garreta J (2004) Pollutants emitted by a cement plant: health risks for the population living in the neighborhood. Environ Res 95:198-206
61. Koh D-H, Kim T-W, Jang SH, Ryu H-W (2011) Cancer Mortality and Incidence in Cement Industry Workers in Korea. Saf. Health Work 2:243-249

62. Yang CY, Huang CC, Chiu HF, Chiu JF, Lan SJ, Ko YC (1996) Effects of occupational dust exposure on the respiratory health of portland cement workers. J Toxicol Environ Health 49:581-588

63. Smailyte G, Kurtinaitis J, Andersen A (2004) Mortality and cancer incidence among Lithuanian cement producing workers. Occup Environ Med 61:529-534

64. García-Pérez J, Lope V, López-Abente G, González-Sánchez M, Fernández-Navarro P (2015) Ovarian cancer mortality and industrial pollution. Environ Pollut 205(103-110):2015

65. García-Pérez J, López-Abente G, Castelló A, González-Sánchez M, Fernández-Navarro P (2015) Cancer mortality in towns in the vicinity of installations for the production of cement, lime, plaster, and magnesium oxide. Chemosphere 128:103-110

66. García-pérez et al (2017) Science of the total environment risk of bone tumors in children and residential proximity to industrial and urban areas: new fi ndings from a case-control study. Sci Total Environ 579:1333-1342

67. García-Pérez et al (2016) Breast and prostate cancer mortality and industrial pollution. Environ Pollut 214:394-399

68. Zemba et al (2011) Emissions of metals and polychlorinated dibenzo $(p)$ dioxins and furans (PCDD/Fs) from Portland cement manufacturing plants: inter-kiln variability and dependence on fuel-types. Sci Total Environ 409:4198-4205

69. Harley J (2007) The impact of cement kilns on the environment

70. Guttikunda SK, Goel R (2013) Health impacts of particulate pollution in a megacity-Delhi, India. Environ. Dev 6:8-20

71. Morsali S (2017) Cement production effects on human health with respect to cement lifecycle assessment

72. Valavanidis A, Fiotakis K, Vlachogianni T (2008) Airborne particulate matter and human health: toxicological assessment and importance of size and composition of particles for oxidative damage and carcinogenic mechanisms. J Environ Sci Health Part C Environ Carcinog Ecotoxicol Rev 26:339-362

73. Capital Aggregates INC (2015) Safety data sheet Portland cement kiln dust

74. Emmanuel TF, Alabi OJ (2015) Effects of cement dust on the hematological parameters in Obajana cement factory workers. Eur Sci J 11:1857-7881

75. Marcon et al (2014) Association between PM10 concentrations and school absences in proximity of a cement plant in northern Italy. Int J Hyg Environ Health 217:386-391

76. Pascal et al (2013) A review of the epidemiological methods used to investigate the health impacts of air pollution around major industrial areas. J Environ Public Health 2013:737926

77. Rai PK (2016) Ecotoxicology and environmental safety impacts of particulate matter pollution on plants: implications for environmental biomonitoring. Ecotoxicol Environ Saf 129:120-136

78. Drack JME, Vázquez DP (2018) Ecotoxicology and environmental safety morphological response of a cactus to cement dust pollution. Ecotoxicol Environ Saf 148:571-577

79. Mutlu S, Atici Ö, Kaya Y (2009) Effect of cement dust on diversity and antioxidant enzyme activities of plants growing around a cement factory. Fresenius Environ Bull 18:1823-1827

80. Oran SA, Zahra HMFA (2014) Impact of the cement dust emitted from the South Cement Factory in Tafila/Jordan on plant diversity of the surrounding area. Int J Biodivers Conserv 6:400-414

81. Kumar et al (2008) Impact of dust emission on plant vegetation in the vicinity of cement plant. Environ Eng Manag J $7: 31-35$ 
82. Pilcher NJ (1999) Cement dust pollution as a cause of sea turtle hatchling mortality at Ras Baridi, Saudi Arabia. Mar Pollut Bull 38:966-969

83. Zhang S, Worrell E, Crijns-Graus W (2015) Cutting air pollution by improving energy efficiency of China's cement industry. Energy Procedia 83:10-20
Publisher's Note Springer Nature remains neutral with regard to jurisdictional claims in published maps and institutional affiliations. 